\title{
ADJOINING UNUSUAL NEST SITES OF SNOW GOOSE AND PEREGRINE FALCON
}

\author{
by E. Kuyt, Canadian Wildlife Service, Fort Smith, N.W.T.
}

Spencer G. Sealy has reported the interspecific nesting of four species of Arctic birds observed along the Perry River in the Northwest Territories in 1965 (Blue Jay, 23:168-169). A Peregrine Falcon, Canada Goose, Rough-legged Hawk and Water Pipit all nested on the same outcropping within 300 yards of each other. The purpose of this note is to relate a somewhat similar association.

I spent the period between July 6 and July 10, 1966 along parts of the Thelon River, N.W.T., engaged in making certain collections for use in a Peregrine Falcon study. One of the Peregrine nest sites is well known to field workers who have visited the Aberdeen Lake area. Local Eskimos have indicated that the nest site has been occupied for as long as they can remember. The nest site is merely a low sand hill with scattered boulders, the whole undoubtedly pushed up in earlier years by the action of moving ice. The nest is a depression in the sand amongst boulders and coarse leaves of Lyme-grass (Elymus arenarius). The nest is accessible to any animal wishing to walk up to it. On July 8, 1966 the falcon's nest contained three eggs. Eggs in this nest in previous years were hatching on July 16, 1963 and on July 11, 1964, so it is reasonable to assume that hatching was imminent during our visit in 1966. The nest was not visited by me in 1965 but I think nesting took place as just below the nest we found a cracked, bleached Peregrine egg, devoid of contents. We presumed the egg had rolled from the nest the previous year.

Somewhat earlier, while circling over the falcon's nest before selecting a landing site for our float-equipped aircraft, we spotted a pair of Snow Geese resting on the same "ice-push". Upon walking to the falcon's nest, we were somewhat startled to find that the Snow Geese had their nest in the same place as the Peregrine Falcons. The two nests were only 25 yards apart but boulders along the ridge of the "ice-push" prevented the setting birds from seeing each other. The nest of the Snow Geese contained four downy young, one of which had just emerged from the still-present egg shell. One cracked egg showing no sign of having been incubated was lodged against a stone about five feet below the nest on the slope facing the lake.

No doubt due to the recent hatching of the goslings, the parent geese were extremely reluctant to leave the area, preferring instead to coax the goslings to walk to the lake. That brought the adult geese close to the nest of the Peregrines and subjected them to immediate and violent attacks by both falcons. The falcons stooped not only at the geese but also at the human intruders. On one occasion a Snow Goose took to the air and that spurred the falcons on to redouble their efforts. The goose barely managed to stay airborne as far as the lake's edge. At that point a particularly vicious stoop by the female falcon caused the goose to hit the water with a resounding splash. Three of the goslings finally joined the parents in the water. The fourth gosling, which was not yet dry, was placed near the parents at the water's edge. Although the falcons paid no attention to it, that gosling's chances of survival appeared slim.

Snow Geese are generally colonizers and the only colony known to me in the area-a group of perhaps 30 or 40 pairs of Lesser Snow Geese (Chen h. hyberborea) -is located about 10 miles away near the western end of Aberdeen Lake. Peregrine Falcons and Snow Geese differ widely in their nesting requirements and it is remarkable that in this case the two species were nesting in such close proximity. 